\title{
Chemically modified sugarcane bagasse as a biosorbent for dye removal from aqueous solution
}

\author{
Ho Thi Yeu Ly, Hoang Thi Khanh Dieu, Trinh Minh Tan Sang, Le Nguyen Minh Nha
}

\begin{abstract}
The use of adsorbent prepared from sugarcane bagasse, an agro waste from sugar industries has been studied as an alternative substitute for activated carbon for the removal of dyes from aqueous solution. Adsorbents prepared from sugarcane bagasse modified with citric acid was used as a low-cost biosorbent for removal of dyes from the aqueous solution. Adsorption parameters such as initial pH values, dyes concentrations, adsorbent dosages and contact times were investigated by the batch experiments. The Freundlich and Langmuir adsorption isotherm models were used to evaluate the experimental data. The results showed that the adsorption process of dyes onto the modified sugarcane bagasse leaned towards Langmuir model for MSB and Freundlich for SB. Maximum adsorption capacity of MSB was found to be $8.40 \mathrm{mg} / \mathrm{g}$ at $\mathrm{pH}$ 9. The results showed that the modified sugarcane bagasse with citric acid could be a potential low-priced adsorbent for removal of the color from the aqueous solution.
\end{abstract}

Keywords - sugarcane bagasse, adsorption, dyes, chemical modified, isotherm models

\section{INTRODUCTION}

$\mathrm{D}$ ye production industries and many other industries which use dyes and pigments generate wastewater, which is characteristically high in color and organic content [1]. Dyes are widely used in industries such as textile, rubber, paper, plastic, cosmetic etc. Among these various industries, textile ranks first in usage of dyes for coloration of fiber $[1,2]$.

The textile industry plays an important role in Viet Nam economy. In fact, this industry has been

Received: 05-06-2017; Accepted: 23-03-2018, Published: 31-12-2018

Ho Thi Yeu Ly*, Hoang Thi Khanh Dieu, Trinh Minh Tan Sang, Le Nguyen Minh Nha - Ho Chi Minh City University of Technology and Education

*Email: yeuly@hcmute.edu.vn. significantly the received investment. But, its fast growth leads to concerns in environmental pollution. It was well known that the textile industry consumes a large volume of water and generates a significant amount of wastewater. In textile industries, about $1000 \mathrm{~L}$ of water is used for every $1000 \mathrm{~kg}$ clothes processed. It is estimated about $10-15 \%$ of the dyes were lost in industrial effluent [3, 4]. Discharge of such coloured effluents impart the colour to the receiving water bodies (rivers, stream and lakes) and causes many significant problems such as increasing the toxicity and chemical oxygen demand. It also reduces light penetration which is a derogatory effect on photosynthesis phenomena $[4,5]$. Therefore, wastewater with dyes is very difficult to treat, since the dyes are recalcitrant organic molecules, resistant to aerobic digestion and stable to light, heat and oxidizing agent $[1,6]$.

Many methods have been studied to remove the color from the textile wastewater and other industries using dyes such as adsorption, coagulation/ flocculation, flotation, oxidation, ozonation, membrane filtration, oxidation and physical methods like membrane filtration, ion exchange and electrochemical techniques. Among them, adsorption has been known as an efficient method to removal the colour [1, 4, 7]. Adsorption techniques were used easily with available low cost adsorbents mainly of biological origin. Therefore, many researches have been conducted to find out alternative low-cost adsorbents. Agricultural waste materials are receiving much more attention as adsorbents for the removal of dyes from wastewater due to its low cost and good availability. Many studies have been undertaken for the removals of pollutants by using a variety of materials used as adsorbents such as apple 
pomace [8], sugarcane bagasse [9], Neem leaf powder [10], banana Pith [11], wheat shell [12], palm tree flower [13], Indian rose wood sawdust [14], rice husk [15], peanut shell [16], coir pith [17], sunflower seed husk [18], orange peel [19] and eucalyptus bark [20] for the removal of different dyes from aqueous solutions at different operating conditions. Sugarcane bagasse, a waste from food, sugar and beverage industries, is a potential adsorbent to remove dyes. Many investigations on bagasse as an effective adsorbent for adsorption of organic pollutants [21, 22] and metals. It is usually modified to enhance its adsorption capacity or used to prepare cheap activated carbon [7, 23].

The objectives of our investigation were to investigate the potential of using modified sugarcane bagasse as a low - cost adsorbent to remove dye from aqueous solutions. Due to their low cost, after these materials have been expended, they can be disposed of without expensive regeneration.

\section{MATERIALS AND METHODS}

\section{Preparation of adsorbent}

The clean bagasse pith selectively collected from the canteen in the University of Technology and Education was washed 2 times with distilled water, then left to dry in the oven at $60{ }^{\circ} \mathrm{C}$ overnight. After that, the bagasse was ground and sieved. The fraction of $0.20-0.45 \mathrm{~mm}$ sizes were collected for experiment then the material was boiled with distilled water at $100{ }^{\circ} \mathrm{C}$ to removal all the sugar in its structure and was labeled as SB.

\section{Citric acid modified bagasse}

The sugarcane bagasse (SB) was treated with $\mathrm{NaOH} 0.1 \mathrm{M}$ (solid SD/solution $=1 / 20 \mathrm{w} / \mathrm{v}$ ) to remove lignin in raw sugarcane bagasse. The mixture was agitated at $250 \mathrm{rpm}$ in 2 hours at room temperature. The mixture was filtered and washed with deionized water to neutral and dried at $55^{\circ} \mathrm{C}$ in the oven.

In order to enhance the adsorption capacity of sugarcane bagasse, citric acid was used to modify the SB. 20 gram bagasse was mixed with $500 \mathrm{~mL}$ of citric acid $0.8 \mathrm{M}$ and then was shaken at $250 \mathrm{rpm}$ for $24 \mathrm{~h}$ at room temperature. The bagasse was then separated and put in the oven at $60{ }^{\circ} \mathrm{C}$ overnight. Again, the bagasse was washed several times with distilled water until neutral. The material was dried in an oven at $60{ }^{\circ} \mathrm{C}$. The material which modified by citric acid was labeled as MSB and which was used for this investigation [24]. The products obtained were characterized by FTIR spectra using FTIR system 8400 Model. The surface morphology of the adsorbent was visualised via scanning electron microscopy [SEM] JEOL-5333 (Japan).

\section{Dye solution preparation}

In this study the Direct Fast Turquoise Blue (FBL) was used and it was obtained from the chemist supplier. An accurate weighed quantity of the dye was dissolved in double distilled water to prepared the stock solution $(500 \mathrm{mg} / \mathrm{L})$. Experimental solution of the desired concentration was obtained by successively dilutions. Dye concentration was determined by using absorbance values measured before and after the treatment, at $610 \mathrm{~nm}$, with Hitachi UV Visible Spectrophotometer (model no.: UH5300).

Experiments were carried out at initial $\mathrm{pH}$ values which were controlled by the addition of $1,0 \mathrm{M}$ or $0,1 \mathrm{M}$ of sodium hydroxide, $\mathrm{NaOH}$ or hydrochloric acid, $\mathrm{HCl}$

\section{Experimental methods}

All the experiments were performed in batch mode at room temperature $\left(30{ }^{0} \mathrm{C} \pm 1\right)$. For the initial $\mathrm{pH}$ investigation, a wide ranging from 1 to 11 was used. In each adsorption experiment, 50,0 $\mathrm{mL}$ of the dye solution of known concentration and $\mathrm{pH}$ was added to $100 \mathrm{mg}$ of adsorbents in 250 $\mathrm{mL}$ round bottom flask at room temperature (30 ${ }^{0} \mathrm{C} \pm 1$ ) and the mixture was stirred on a rotary orbital shaker at $250 \mathrm{rpm}$. The sample was withdrawn from the shaker at the predetermined time intervals. The experiment was done by varying the amount of absorbents (0.1 to 1.2 $\mathrm{mg} / 50 \mathrm{~mL}$ ), concentration of dye solution (40$160 \mathrm{mg} / \mathrm{L})$ and $\mathrm{pH}(1-11)$ after the equilibrium time. The effect of the contact time was examined by added $0.4 \mathrm{~g}$ adsorbent to $50 \mathrm{~mL}$ of adsorbate at 
a concentration $20 \mathrm{mg} / \mathrm{L}$. For all experiments, the supernatant was used to check the colour removal efficient which was measured by the initial and the final concentration $\left(\mathrm{C}_{0}\right.$ and $\left.\mathrm{C}\right)$ of the dye solution. The formula was:

$$
\text { Efficiency } \%=\frac{C_{0}-C}{C_{0}} \times 100
$$

\section{RESULTS AND DISCUSSION}

\section{Characteristics of adsorbents}

The surface morphology of SB and MSB visualized via scanning electron microscopy, are shown in Fig. 1 and Fig. 2.

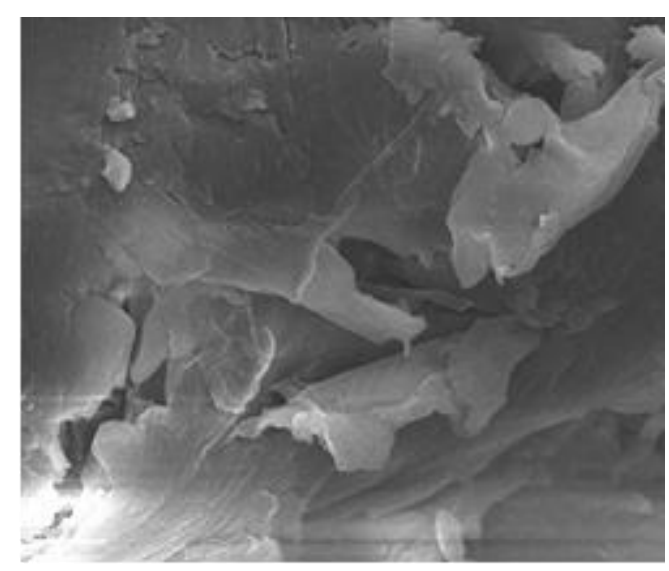

Fig.1. SEM of SB

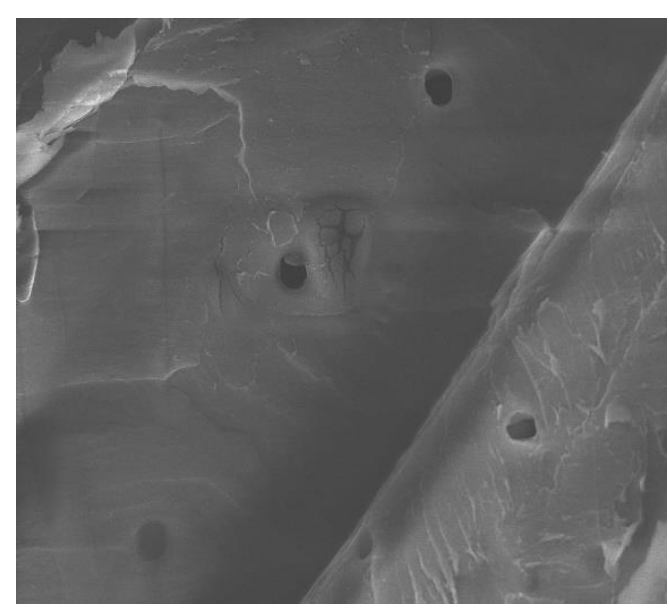

Fig. 2. SEM of MSB
SEM of MSB shown that the surface raw bagasse which was modified with citric acid became flatter than the surface of the raw sugarcane bagasse.

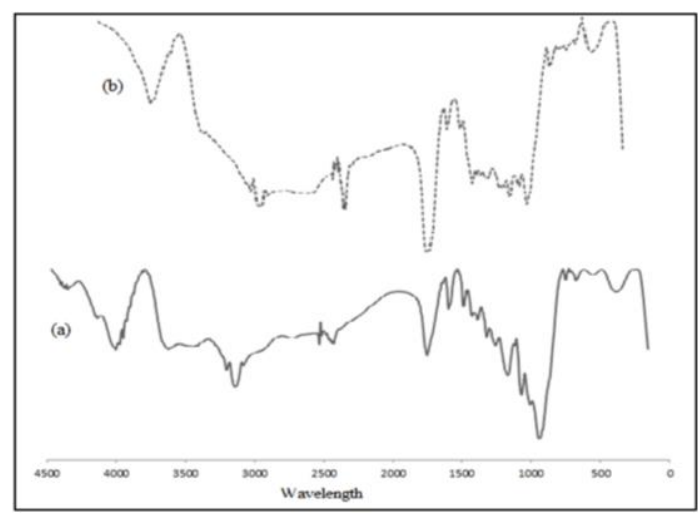

Fig. 3. FITR spectra of (a) raw sugarcane bagasse and (b) modified sugarcane bagasse with citric acid

The spectra of raw bagasse (SB) before (a) and (b) after modification with citric acid (MSB) are shown in Fig. 3. When comparing the FTIR spectrum of MSB to the one of $\mathrm{SB}$, the higher intensity of the peak at $1730 \mathrm{~cm}^{-1}$ confirmed by the presence of carboxyl groups in citric acid, leading to the increase the adsorption capacity of MSB for dyes.

\section{Effect of pH}

The removal efficiency of the sugarcane bagasse (SB) and the modified sugarcane bagasse (MSB) at different $\mathrm{pH}$ is shown in Fig. 4. The results showed that the percentage of dye removal decreased with increasing $\mathrm{pH}$ values. At the low $\mathrm{pH}$ region, the $\mathrm{pH}$ range of 1 to 4 , the same adsorption efficiency of SB and MSB became meaningless. When the $\mathrm{pH}$ reached to 5 , the removal efficiency of two SB and MSB started to be different. The percentage of colour removal of MSB was higher comparing with those of SB. As shown in Fig. 4, at $\mathrm{pH} 1-2$, the dye was removed completely for both SB and MSB. At $\mathrm{pH} 9$, the maximum percentage efficiency of dye removals were observed, $18 \%$ for SB and $64 \%$ for MSB. 


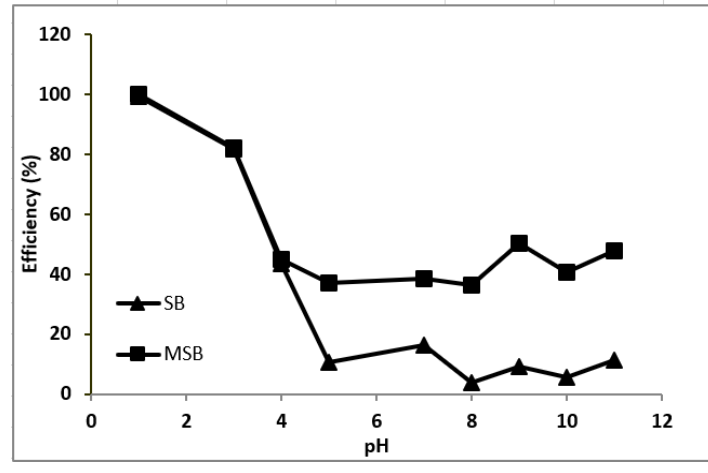

Fig. 4. The dye removal efficiency at different $\mathrm{pH}$, adsorbent mass $=0.1 \mathrm{~g}, \mathrm{C}_{0}=20 \mathrm{mg} / \mathrm{L}$

This phenomenon could be explained that at the $\mathrm{pH}$ low, the dye became active and it attached to the cellulose structure of the materials. However, the adsorption process at very low $\mathrm{pH}$ was not useful due to a large amount of acid must be used to neutralize, leading to high cost of the treatment. Therefore, at $\mathrm{pH} 9$ was used for the investigation of the adsorption process.

\section{Effect of the adsorbent dosage}

Fig. 5 illustrated the adsorption efficiency of the modified sugarcane bagasse at different dosages.

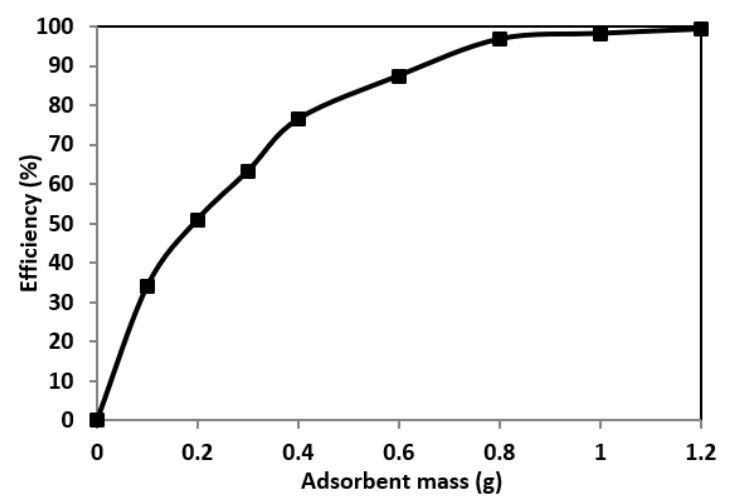

Fig. 5. Dye removal efficiency at different adsorbent dosages $\mathrm{pH}=9, \mathrm{C}_{0}=50 \mathrm{mg} / \mathrm{L}$

It was observed that the adsorption efficiency increased with increasing the mass of the adsorbent. The percentage adsorption increased from $34.1 \%$ at a dose of $0.1 \mathrm{~g}$ to $99.3 \%$ at a dose of $1.2 \mathrm{~g}$. Obviously, the more material added, the more active site for the dye to attach on. After dose of $0.4 \mathrm{~g}$, the adsorption reached an equilibrium as the increase became stable.

At any given adsorbent dosage, the final $\mathrm{pH}$ in the presence of dye was higher compared to those in the absence of dye. This was attributed to the anion-exchange reaction between dye anion and surface-active groups on the adsorbent [1].

\section{Effect of initial dye concentration}

Fig. 6 represented the change of adsorption ability at different dye concentration. The higher initial concentration was, the less dye was removed. With the range of initial concentration was $40-160 \mathrm{mg} / \mathrm{L}$, the efficiency dropped from $69 \%$ to $35.8 \%$.

Table 1 showed the Freundlich and Langmuir isotherm parameter data. Maximum adsorptive capacity of MSB was nearly twice as SB. This improved the efficiency of the modification of MSB.

Table 1. Freundlich and Langmuir isotherm parameters

\begin{tabular}{|l|l|l|l|}
\hline & Parameter & $\mathrm{SB}$ & MSB \\
\hline \multirow{4}{*}{ Freundlich } & $\mathrm{K}$ & 20.2675 & 0.4271 \\
\cline { 2 - 4 } & $\mathrm{n}$ & 1.4546 & 2.7273 \\
\cline { 2 - 4 } & $\mathrm{R}^{2}$ & 0.9896 & 0.9582 \\
\hline \multirow{3}{*}{ Langmuir } & $\mathrm{k}_{\mathrm{L}}$ & 0.0137 & 0.0503 \\
\cline { 2 - 4 } & $\mathrm{Q}_{\max }(\mathrm{mg} / \mathrm{g})$ & 4.57 & 8.40 \\
\cline { 2 - 4 } & $\mathrm{R}^{2}$ & 0.9601 & 0.9848 \\
\hline
\end{tabular}

From $\mathrm{R}^{2}$, the result showed that the adsorption process of both SB and MSB were followed both isotherm models. But SB seemed to fit Freundlich model while MSB much fitted Langmuir model.

MSB's Q $Q_{\max }$ was compared to other adsorbents in Table 2. Comparing to other materials used to remove dyes from aqueous solution, the results showed that the MSB could be used for removal of dyes from the textile wastewater. 


\section{CHUYÊN SAN KHOA HỌC TỬ NHIÊN, TẬP 2, SỐ 6, 2018}

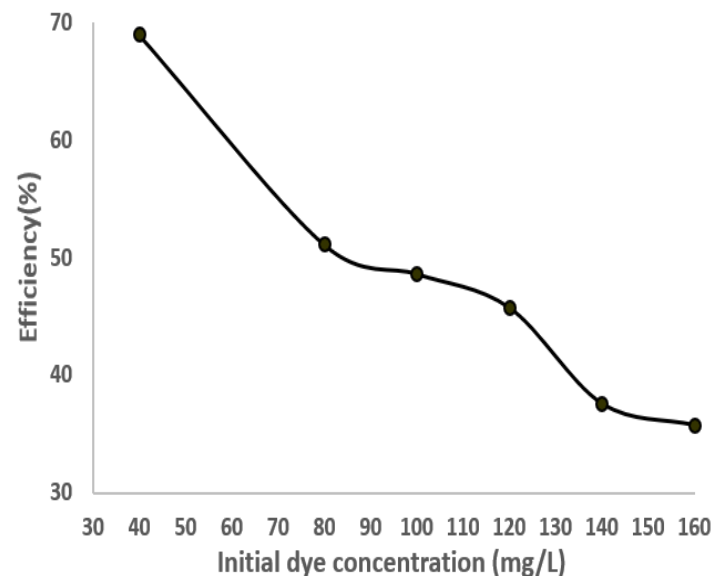

Fig. 6. The dye removal efficiency at different initial dye concentrations, $\mathrm{pH}=9$, adsorbent dose $=0.4 \mathrm{~g}$

This result from the surface active sites of the adsorbent was limited since the dose was constant. When the color increased, there was not enough the space to the adsorption which led to the decline in the efficiency.

\section{Effect of the contact time}

The contact time effect on the adsorption was shown in Fig. 7. As shown in the results, from 15 minutes to 4 hours, the adsorption percentage of removal increased from $72.5 \%$ to $91.5 \%$. The longer shaken time was, the more contact between the adsorbent and the adsorbate, which meant the dye had more chances to attach onto the material's cellulose chains. Hence, much dye adsorbed, made the colour removal efficiency higher. After 15 mins, the efficiency still rose, but not much. So, 15 mins could be considered as the optimum contact time.

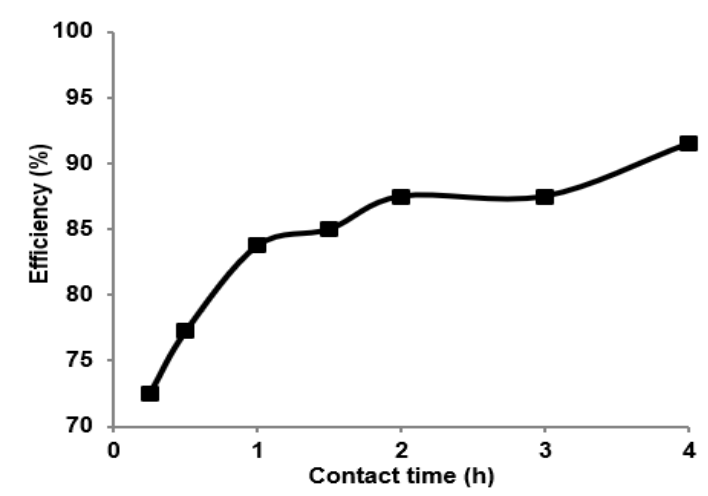

Fig. 7. The dye removal efficiency at different contact times, $\mathrm{pH}=9$, adsorbent dose $=0.4 \mathrm{~g}, \mathrm{C}_{0}=20 \mathrm{mg} / \mathrm{L}$

\section{Adsorption isotherm}

Freundlich and Langmuir adsorption isotherm models were used to evaluate the experimental data.

Table 2. Natural forms of agricultural waste and its dye adsorption capacities

\begin{tabular}{|l|c|c|}
\hline Adsorbent & $\mathrm{Q}_{\max }(\mathrm{mg} / \mathrm{g})$ & Reference \\
\hline Alunite (Turkey) & 2.85 & {$[25]$} \\
\hline Glass powder & 4.03 & {$[26]$} \\
\hline Coir pith & 6.72 & {$[27]$} \\
\hline Sugarcane bagasse & 5.78 & {$[28]$} \\
\hline Rice husk & 40.59 & {$[29]$} \\
\hline Walnut bark & 15.1 & {$[30]$} \\
\hline Cherry saw dust & 39.00 & {$[31]$} \\
\hline Banana peel & 20.08 & {$[32]$} \\
\hline Orange peel & 0.07 & {$[33]$} \\
\hline $\begin{array}{l}\text { Modified sugarcane } \\
\text { bagasse }\end{array}$ & 8.40 & This work \\
\hline
\end{tabular}

\section{CONCLUSION}

Normal sugarcane bagasse pith (SB) and sugarcane bagasse modified with citric acid (MSB) have been studied for the adsorption of textile dye (FBL). The adsorption efficiency of MSB increased with increasing contact time and decreased with increasing initial dye concentration. Optimum condition for adsorption was $\mathrm{pH} 9$, and the adsorbent mass was $0.4 \mathrm{~g}$. The results obtained from the studies showed that the adsorption process of MSB for the Direct Fast Turquoise Blue (FBL) followed the Langmuir and the Freundlich isotherm models in the order of Freundlich < Langmuir. The results showed that the bagasse pith had the potential to be a competitive alternative natural adsorbent.

Acknowledgments: The authors are grateful to Ho Chi Minh City University of Technology and Education for funding this research. T201755TÐ Code. 


\section{REFERENCES}

[1]. S.A. Saad, K.Md. Isa, R. Bahari, "Chemically modified sugarcane bagasse as a potentially low - cost biosorbent for dye removal", Desalination, 246, pp. 123-128, 2010.

[2]. M. Santhi, P.E. Kumar, B. Muralidharan, "Removal of malachite green dyes by adsorption onto activated carbon - $\mathrm{mno}_{2}$ - nano composite - kinetic study and equilibrium isotherm analyses", Journal of Applied Chemistry, 8, Is. 4 Ver. I, pp. 33-41, 2015.

[3]. E. Forgacs, T. Cserhati and G. Oros, "Removal of synthetic dyes from wastewaters: a review", Environ. Int., 34, pp. 953-971, 2004.

[4]. K. Murali*, R.N. Uma, "Removal of basic dye (methylene blue) using low cost biosorbent: water hyacinth", International Journal of Advanced Engineering Technology, vol. 7, Is. 2, pp. 386-391, 2016.

[5]. G. Crini, "Non-conventional low-cost adsorbents for dye removal: a review", Bioresource Technology, 97, 9, 1061-1085, 2006.

[6]. O.S. Amuda, A.O. Olayiwola, A.O. Alade, A.G. Farombi, S.A. Adebisi, "Adsorption of methylene blue from aqueous solution using steam-activated carbon produced from Lantana camara stem", Journal of Environmental Protection, 5, pp. 1352-1363, 2014.

[7]. N.K. Amin, "Removal of reactive dye from aqueous solutions by adsorption onto activated carbons prepared from sugarcane bagasse pith", Desalination, 223, pp. 13, 152-161, 2008

[8]. T. Robinson, B. Chandran, P. Nigam, "Removal of dyes from a synthetic textile dye effluent by biosorption on apple pomace and wheat straw", Water Res, 36, pp. 2824-2830, 2002.

[9]. S.S. Azhar, A.G. Liew, D. Suhardy, Farizul Hafiz K, Irfan Hatim M.D., "Dye removal from aqueous solution by using adsorption on treated sugarcane bagasse", Am. J. Appl.Sci., 2, pp. 1499-1503, 2005.

[10]. K.G. Bhattacharyya, A. Sarma, "Adsorption characteristics of the dye, brilliant green, on neem leaf powder", Dyes Pigm, 57, pp. 211-222, 2005.

[11]. C. Namasivayam, D. Prabha, M. Kumutha, "Removal of direct red and acid brilliant blue by adsorption on to banana pith”, Bioresour. Technol., 64, 77-79, 1998.

[12]. Y. Bulut, A.H. Aydin, "A kinetics and thermodynamics study of methylene blue adsorption on wheat shells, Desalination", 194, 259-267, 2006.

[13]. M.S. Kini, B. Saidutta, V.R. Murty, "Studies on biosorption of methylene blue from aqueous solutions by powdered palm tree flower (Borassus flabellifer)", International Journal of Chemical Engineering, dx.doi.org/10.1155/2014/306519, 2014.

[14]. V.K. Garg, M. Amita, R. Kumar, R. Gupta, "Basic dye (methylene blue) removal from simulated wastewater by adsorption using Indian Rosewood sawdust": a timber industry waste, 63, pp. 243-250, 2004.

[15]. Y. Guo, S. Yang, W. Fu, J. Qi, R. Li, Z. Wang, et al. "Adsorption of malachite green on micro and mesoporus rice husk based activated carbon", Dyes Pigments, 3, 219-249, 2003.
[16]. A. Abbas, S. Murtaza, K. Shahid, M. Munir, R. Ayub, S. Akber, "Comparative study of adsorptive removal of congo red and brilliant green dyes from water using peanut shell”, Middle-East J. Sci. Res., , 11, pp. 828-832, 2012.

[17]. K.D. Namasivayam, "Experimental and kinetic studies on methylene blue adsorption by coir pith carbon", Bioresour. Technol., 98, pp. 14-21, 2007.

[18]. S.T. Ong, P.S. Keng, S.L. Lee, M.H. Leong, Y.T. Hung, "Equilibrium Studies for the removal of basic dye by sunflower seed husk (Helianthus annuus), International Journal of Physical Sciences, 5, 8,1270-1276, 2010.

[19]. C. Namasivayam, N. Muniasamy, K. Gayatri, M. Rani, K. "Ranganathan, Removal of dyes from aqueous solutions by cellulosic waste orange peel", Bioresour. Technol., 57, pp. 37-43, 1996.

[20]. L.C. Morais, O.M. Freitas, E.P. Goncalves, Vasconcelos L.T., Beca C.G., "Reactive dyes removal from wastewaters by adsorption on eucalyptus bark: variables that define the process", Water Res., 33, 979-988, 1999.

[21]. A. Demirbas, "Agricultural based activated carbon for the removal of dyes from aqueous solutions: a review", Journal of Hazardous Materials, pp. 1-9, 2009.

[22]. Y. Fu, T. Viraraghan, "Removal of C.I Acid Blue 29 from an aqueous solution by 'Aspergillus niger',, American Associate Textile Chemistry Color Revolution, 1, pp. 36-40, 2001.

[23]. N.K. Amin, "Removal of reactive dye from aqueous solutions by adsorption onto activated carbons prepared from sugarcane bagasse pith". Desalination, 223, 1-3, pp. 152-161, 2008.

[24]. B. Hameed, F. Daud, "Adsorption studies of basic dye on activated carbon derived from agricultural waste: Hevea brasiliensis seed coat", Chemical Engineering Journal, 139, 1, pp. 48-55, 2008.

[25]. M. Ozacar, A.I. Sengil, "Adsorption of reactive dyes on calcined alunite from aqueous solutions", Journal of Hazardous Materials B98, pp. 211-224, 2003.

[26]. G. Atun, G. Hisarli, "Adsorption of carminic acid, a dye on glass powder", Chemical Engineering Journal, 95, pp. 241-249, 2003.

[27]. C. Namasivayam, D. Kavitha, "Removal of Congo red from water by adsorption onto activated carbon prepared from coir pith, an agricultural solid waste", Dyes and Pigments, 54, pp. 47-58, 2002.

[28]. W.T. Tsai, C.Y. Chang, M.C. Lin, S.F. Chien, H.F. Sun, M.F. Hsein, Adsorption of acid dye onto activated carbon prepared from agricultural waste bagasse by $\mathrm{ZnCl} 2$ activation, Chemosphere, 45, 51-58, 2001.

[29]. V. Vadivelan, K.V. Kumar, "Equilibrium, Kinetics, Mechanism, and Process design for the sorption of methylene blue onto rice husk", Journal of Colloid and Interface Science, 286, 90-100, 2005.

[30]. K. Bushra, Y. Azra, F. Muhammed, L. Lubna, Benish, "Study of Colour measurements of leather dyed with walnut bark natural dye", Journal of Industrial Resources, 53, pp. 252-257, 2010.

[31]. F. Ferrero, "Dye removal by low cost adsorbents: hazelnut shell in comparison with wood saw dust", 
Journal of Hazardous Materials, 142, pp. 144-152, 2007.

[32]. G. Annadurai, R.S. Juang, D.J.S. Lee, "Use of Cellulose Wastes for Adsorption of dyes from aqueous solutions by banana peel waste: kinetic, equilibrium and thermodynamic studies", Desalination, 271, pp. 80-87, 2002.

[33]. Mane, R. V. Bhusari, "Removal of colour (dyes) from textile effluent by adsorption using orange and banana peel", International Journal of Engineering Research and Applications, vol. 2, no. 3, pp. 1997-2004, 2012.

\title{
Bã mía biến tính hóa học như là một chất hấp phụ sinh học nhằm loại bỏ màu của dung dịch thuốc nhuộm từ dung dịch lỏng
}

\author{
Hồ Thị Yêu Ly*, Hoàng Thị Khánh Diệu, Trịnh Minh Tấn Sang, Lê Nguyễn Minh Nhã \\ Trường Đại học Sư phạm Kỹ thuật TP. HCM \\ Email tác giả liên hệ: yeuly@hcmut.edu.vn \\ Ngày nhận bản thảo: 05-06-2017; Ngày chấp nhận đăng: 23-03-2018; Ngày đăng: 31-12-2018
}

Tóm tắt-Việc sử dụng chất hấp phụ được chuẩn bị từ mía, một chất thải nông nghiệp từ các ngành công nghiệp mía đường đã được nghiên cứu như là một chất thay thế cho than hoạt tính để loại bỏ màu thuốc nhuộm từ dung dịch lỏng. Chất hấp phụ chuẩn bị từ mía được biến tính với citric acid đã được sử dụng như một chất hấp phụ sinh học chi phí thấp để loại bỏ màu thuốc nhuộm từ nước thải dệt. Các thông số hấp phụ như giá trị pH ban đầu, nồng độ thuốc nhuộm, lượng chất hấp phụ và thời gian tiếp xúc được nghiên cứu bằng các thí nghiệm dạng mẻ. Các mô hình đẳng nhiệt hấp phụ
Freundlich và Langmuir được sử dụng để đánh giá các dữ liệu thực nghiệm. Kết quả nghiên cứu cho thấy quá trình hấp phụ của thuốc nhuộm tuân theo mô hình Freundlich đối với bã mía chưa biến tính (SB), tuân theo mô hình Langmuir đối với bã mía đã biến tính bằng citric acid (MSB). Khả năng hấp phụ tối đa của MSB là $8,40 \mathrm{mg} / \mathrm{g}$ tại $\mathrm{pH}=9$. Kết quả cho thấy rằng bã mía biến tính sau khi được xử lý, biến tính bằng citric acid có thể là một chất hấp phụ tiềm năng có thể loại bỏ màu của dung dịch thuốc nhuộm.

Tù khóa-bã mía biến tính, hấp phụ, thuốc nhuộm, dung dịch lỏng, các mô hình cân bằng 